\title{
THE NEED FOR A LEGAL-WRITING COURSE IN THE SOUTH AFRICAN LLB CURRICULUM
}

\author{
Neels Swanepoel
}

BA LLB LLM LLD

Associate Professor of Procedural Law

University of the Free State

Attorney of the High Court of South Africa

Elizabeth Snyman-Van Deventer

Bluris LLB LLM LLM LLD

Professor of Mercantile Law

University of the Free State

Advocate of the High Court of South Africa

\section{SUMMARY}

Students are generally unprepared to study law. Unpreparedness includes language and writing deficiencies. Legal-writing courses at law school only lay the foundation for these skills that have to be developed and improved over many years of practice. Law schools and the organized profession should accept joint responsibility for laying this foundation. A substantial part of most legal-writing courses must include language training. Legal writing is generally not regarded as necessary by many South African law faculties. The main challenge in the area of developing legalwriting courses in South Africa involves the fact that legal academics have not been formally trained to teach language and writing. It is proposed that a course is introduced for law teachers in and that they undergo training that will enable law lecturers to present these courses themselves.

\section{INTRODUCTION}

The design of a legal-writing course for inclusion in the South African LLB curriculum occurs against the backdrop of a number of factors which must be considered. Firstly, there is the plethora of criticism by professionals with regard to the quality of law graduates produced by South African universities. ${ }^{1}$ Secondly, there is the sad reality, but mammoth challenge,

Swanepoel, Karels and Bezuidenhout "Integrating Theory and Practice in the LLB Curriculum" 2009 JJS 99-111; see also Laser "Educating for Professional Competence in the Twenty-first Century: Educational Reform at Chicago-Kent College of Law" 1992/1993 
regarding the general unpreparedness of students to study law. In 1998, the postgraduate LLB degree providing admission to both the attorneys' and advocates' professions in South Africa was changed from a postgraduate, five-year study programme to an undergraduate, four-year study programme. In addition, the need for the inclusion of legal skills and, at many South African universities, clinical legal education, was formalized. Unpreparedness includes language and writing deficiencies. This is a universal problem that occurs for various reasons. Vinson ${ }^{2}$ advocates that legal-writing courses at law school only lay the foundation for a skill that has to be developed and improved over many years of practice and one for which law schools and the organized profession should accept joint responsibility.

It is clear that a legal-writing course for inclusion in the South African LLB curriculum cannot be developed without devoting a substantial part of that course to language training. Furthermore, the presentation of a writing course, as well as its subject matter, should be reinforced and inculcated in all theory/content-based subjects of the LLB curriculum. Law teachers themselves ought to teach legal writing skills, which may require them to undergo a substantial amount of language training themselves, as well as the willingness to engage in cross-departmental and cross-faculty collaboration with colleagues.

\section{THE BACKGROUND AND CHALLENGES OF LEGAL WRITING AT SOUTH AFRICAN LAW FACULTIES}

Whereas legal writing as a separate and independent course is now seen as an important component of most law curricula in the United States and also in Canada, this is not necessarily the case in many South African law faculties. There may be a variety of valid explanations for this, including the fact that a Juris Doctor (JD) graduate (the first law degree after completion of an undergraduate degree or also referred to as a first professional degree) in the United States writes the bar examination immediately upon completion of the final JD examination. Therefore, US graduates do not receive any training with regard to professional preparation as is the case in South Africa, where LLB graduates must complete either a period of pupillage or articles/community service before being permitted to write the admission examinations in respect of either the bar or the side-bar. Another distinguishing factor between the two systems is that, whereas in South Africa the LLB degree is an undergraduate degree, the American counterpart, the JD, is a postgraduate degree. It is therefore to be expected that a typical US law school will be much more focused on career preparation than a South African law faculty. In view of the challenges faced

Chicago-Kent LR 243-280; and Stuckey Best Practices for Legal Education. University of South Carolina: CLEA (2007) 26 and further.

2 Vinson "Improving Legal Writing: A Life-long Learning Process and Continuing Professional Challenge" 2005 Touro LR 507. 
by South African law faculties as described below, and the remarks made in the introduction, it is respectfully proposed that the institution of a legalwriting course as a regular, core feature of the LLB curriculum in South Africa is necessary. While a legal-writing course is only one aspect of the holistic objective to teach students advocacy skills during the LLB programme, it is an extremely important one.

\section{The current state of higher education in South Africa}

According to an in-depth article in Finweek ${ }^{3}$ based on comprehensive research by the well-known, Pretoria-based Ask Africa on South African universities, the current situation pertaining to South African tertiary-level education is described as being in "a stable crisis", since South African universities are generally not producing graduates who are suitable for the market place. It points out that the proposal of the then Minister of Education, Kader Asmal, for a restructured system of higher education in 2002 was solely driven by political expediency (greater access to higher education by previously disadvantaged students and therefore increased outputs by numbers), but failed to consider "the unintended downward spiral in the quality of university output". Many students are insufficiently prepared by schools for university. The first issue identified for urgent need by Government is "a national strategy for co-operation and collaboration to share the national burden of educating unprepared students". ${ }^{4}$ While this research refers to students generally entering tertiary institutions, all law teachers will attest to the fact that law students are, in many instances, insufficiently prepared for tertiary legal education. However, this problem does not seem to be a uniquely South African problem. In the UK, for example, students from social groups previously excluded from UK higher education are also unprepared for the demands of higher education. ${ }^{5}$

\section{The lack of language skills and numeracy skills}

At the University of the Free State (UFS), it is compulsory for students in their first year of study to enrol for a course offered by the Department of English in Legal English. However, most of the Faculty staff are unaware as to the specific content of the course as well as the standard of competency required to pass the course. Many law teachers ${ }^{6}$ hide behind the fact that they are lawyers and not linguists. Furthermore, while they complain about

3 Anonymous "A 'Stable Crisis'” 26 February 2009 Finweek 3-30 http://www.Fin24.com/ Finweek?This-weeks-survey/SA-Tertiary-Terrain-2009-20090220 (accessed 2011-09-07).

Anonymous 26 February 2009 Finweek 4.

5 Lillis and Turner "Student Writing in Higher Education: Contemporary Confusion, Traditional Concerns" 2001 Teaching in Higher Education 57.

6 We submit this as a personal observation that it is a general complaint from South African law teachers at most conferences, workshops and in discussions that we do not have the specialized knowledge nor the time to teach the language skills needed to remedy the language problems of law students. 
the regressive language proficiency exhibited by students in tests, assignments and examinations, they do little to become involved themselves. The overall extent of this language and writing deficiency is demonstrated by the fact that the South African attorneys' profession, through its Legal Development and Education programme (LEAD), is presenting a short post-graduate course at various venues in South Africa for candidate attorneys. This course is aimed at addressing the basic legalwriting deficiencies. ${ }^{7}$ Although the outcomes are not specifically stated in the course material, it is worth noting that $75 \%$ of the course consists of Basic English. As far as the UFS is concerned, the policy states that a student who enters the institution and scores lower than $50 \%$ on the Alternative Admission Research Project (AARP) language test, must complete a language-development course during his or her first year. The 2009 AARP Report revealed that approximately $50 \%$ of the first-year students at the UFS passed the language test. As far as mathematical literacy is concerned, the AARP Report revealed that, while only $0,4 \%$ of students scored under $50 \%$ in Grade 12 Mathematical Literacy, $80,9 \%$ of students scored below $50 \%$ in the psychometric mathematical tests. This underscores the lack of writing and numeracy skills currently experienced in law students.

There are additional findings and recommendations in the 2009 AARP Report that must be highlighted and which fully corroborate the findings with regard to South African tertiary education referred to in 11 above (results of the AARP Tests written in February 2009):

"(1) There is a discrepancy between the level of performance between National Senior Certificate (NSC) Grade 12 and the levels of performance in the psychometric tests. This, however, is an understatement.

(2) Under recommendations (AARP Report 7), the following appears:

'Given that language competence is critical for success in all areas, there is a need to consider extending the language development currently offered. This could take various forms, such as including language development modules in all years of a qualification, exploring ways of integrating language development with content subjects, possibly using the content-based instruction approach, exploring ways of ensuring that lecturers in all subject areas are sensitive to the need to improve students' language competence and so feedback on language use is included across all subjects.'

(3) As far as language testing is concerned, research at the AARP centre at the University of Cape Town has indicated that students scoring below $45 \%$ should not be admitted to university. Those scoring between $45 \%$ and $65 \%$ require additional language support and only students scoring above $65 \%$ have a reasonable chance of being successful at university. The mean score of the UFS Faculty of Law was $51,816 \%$. This clearly illustrates the level of unpreparedness of students at this institution to undertake the study of law, especially considering the fact that the mastery of language is the most basic, yet imperative skill required to practice law. This unpreparedness may very well be applicable to many South African universities. Before a legal-writing course can be developed, it is necessary to make sure that the enormous language deficiency is dealt with adequately."

7 LEAD Practice Manual Legal Writing 2009. 
The design and implementation of a legal-writing course for inclusion in the South African LLB curriculum is therefore imperative; not only to equip students more thoroughly for professional life but also as a strategy for restructuring and revamping curricula in order to meet modern demands and the realities of the market place. However, the design and implementation of a legal-writing course without having done thorough preparation may be compared to "flying an airplane while still building it".

\section{The integration of skills and theory}

It would be unwise to introduce a legal-writing course if the only good writing to be produced is that which is produced during the course itself. Good legal writing (and many other legal skills) may very well be inculcated or reinforced in a broad spectrum of traditional theory- or content-based/doctrinal subjects.

It is our own experience and substantiated by general comments made by academics at the UFS that law students fail to view the entire curriculum as an integrated process. Each subject is considered by students to exist within its own "compartment" so that when one teaches the drafting of pleadings, for example, students neglect to link or apply the theory they were taught in a wide range of theoretical, content-based or doctrinal subjects to legal writing/drafting.

Upon introspection, however, it may be suggested that the same charge can, in many instances, be levelled against a number of academics themselves regarding their aversion to take ownership of the entire LLB curriculum, which inevitably requires inter- and cross-departmental, as well as cross-faculty collaboration between law teachers.

\section{The so-called "skills" courses}

In many South African law faculties, such as the one at the UFS, aspects of what could constitute parts of a legal-writing course are already included under the wide rubric of a subject known as "Legal Practice". This also applies to a subject called "Legal Skills", which is compulsory for law students on the extended LLB curriculum, that is, students who have been assessed according to UFS criteria for admission to law, and who have been advised to complete the LLB over five, instead of four years. The first year of the so-called "Five-year LLB" is devoted to the development of language and other skills.

The "skills" courses have been designed and instituted at many law schools for the very purpose of teaching effective advocacy (including legal writing) and, in many instances, these have produced positive results. However, it is when teaching these skills courses, that one realizes that traditional theory subjects may also play a crucial role in achieving the ideals

8 Anonymous 26 February 2009 Finweek 13. 
of effective advocacy as a whole. How this may be achieved, however, is a debate that is noticeably and peculiarly absent from academic discourse on the general restructuring and transformation of the LLB curriculum. ${ }^{9}$ The reasons for this may be many and varied though, centrally, it still revolves around the debate as to whether law faculties or law schools are to produce "legal mechanics" instead of "legal scholars". An American report stated that "[u]nderlying any discussion of legal education, however, is the tension between legal education as an intellectual endeavor and legal education as training to practise a profession". ${ }^{10}$ This is unfortunate, since the solution ought to be found somewhere in the middle.

The result of this largely absent discourse on how to achieve integration of skills and content in the LLB curriculum, however, is that opportunities are lost with regard to the teaching or inculcation of many important legal skills in subjects that traditionally convey theory of law alone. Just as the teaching of legal skills requires foundational theoretical knowledge, so too, the mastery of theory requires certain foundational skills. Achtenberg ${ }^{11}$ from within the American context and with regard to legal-writing courses, states that:

"Legal writing and research require personnel with three major skills. The course depends on substantial administrative ability. It demands sophistication in the nuances of writing. And third, it involves some degree of competency in several areas of substantive law."

\section{Effective advocacy}

It is necessary to identify the main elements of what constitutes effective advocacy and, following this, to build upon each element and skill in a planned and structured way in order to achieve a holistic whole. In order for a skill to develop, it needs a basic competency. Skill in itself cannot develop without certain foundational competencies. Achtenberg ${ }^{12}$ claims:

"Effective advocacy is the ultimate goal of law-school training. Persuading a person to move from point A to point B by the use of language is the lawyers' primary skill. A grasp of legal-research methodology, understanding legal conventions, being able to analyze and synthesize and having 'lawyer-like' thought patterns are all building-blocks to the ultimate function of a lawyeradvocacy."

An enquiry into what constitutes "effective advocacy" also leads to an inquiry into the most essential skills with regard to being a lawyer as required by legal practice. Much has been written nationally and internationally about the essential skills of a lawyer and it is worth noting that most of these skills

Swanepoel, Karels and Bezuidenhout 2009 JJS 101.

Achtenberg "Appellate Litigation Skills Training: The Role of the Law Schools. Report and Recommendations of the Committee on Appellate Skills Training Appellate Judges' Conference Judicial Administration Division American Bar Association" 1985 Cincinnati LR 130.

11 Achtenberg "Legal Writing and Research: The Neglected Orphan of the First Year" 1975 University of Miami LR 219.

12 lbid. 
are generically described as no less than effective advocacy skills. ${ }^{13}$ Laser $^{14}$ lists the ten "fundamental lawyering skills" identified by the American Bar Association as (a) problem-solving, (b) legal analysis and reasoning, (c) legal research, (d) factual investigation, (e) communication, (f) counselling (g) negotiation, (h) litigation and alternative dispute resolution, (i) organization and management of legal work and (j) recognizing and resolving ethical dilemmas.

All the same, it should be remembered that a skill should, or could, later develop into an art: "the art of lawyering". Because of the constraints faced in tertiary education described above, developing skills into arts cannot be the immediate objective, but is nevertheless worth taking note of. ${ }^{15}$

The following are the elements that constitute effective advocacy.

\section{Comprehension and language}

Comprehension is simply the ability to understand the oral or written word and is achieved through the medium and mastery of a given language. ${ }^{16}$

The first step will be to ensure that a basic level of competency in language is in place in order for that to develop into the mastery of legal language and, eventually, legal writing. Here it is important to heed the remarks above that, if NSC results are used as criteria with regard to which admission to the study of law occurs, those results, at least for the present, in South Africa, are suspect. Institutions of higher education should therefore revisit their admission criteria and exhibit innovative thinking in overcoming the challenges they are currently faced with.

\section{Analysis and synthesis of legal texts (legal method)}

Once it has been ensured that a certain standard of comprehension through language has been achieved by students, the second key ability/competency needed to achieve effective advocacy in a holistic manner, is to proceed to the mastery of analysis of a legal text, which inevitably leads to logical thinking, structuring and, perhaps most importantly, solving legal problems. Boyer $^{17}$ is of the opinion that legal writing is the only course in which analysis

13 See, eg, Profile of a Legal Practitioner and Learning Assumed to be in Place for an LLB Graduate when he or she Commences his/her Training for Admission as an Advocate or Attorney by the Law Society of South Africa.

14 Laser "Educating for Professional Competence in the Twenty-first Century: Educational Reform at Chicago-Kent College of Law" 1992/1993 Chicago-Kent LR 247.

15 Laser 1992/1993 Chicago-Kent LR 253.

16 See, eg, Hedrick and Cunningham "The Relationship Between Wide Reading and Listening Comprehension of Written Language" 1995 Journal of Reading Behavior 425 and further; and the following websites were all accessed 2012-02-03: http://www.teachfind.com/ national-strategies/developing-language-comprehension-skills; http://www.sedl.org/reading/ frame work/elements.html; http://www.yarcsupport.co.uk/documents/devreadcomp.pdf; and http://www.thefreedictionary.com/comprehension.

17 Boyer "Legal Writing Programs Reviewed: Merits, Flaws, Costs, and Essentials" 1986 Chicago-Kent $L R 25$ and further. 
is systematically taught, whereas in other courses, it is hoped that the student will acquire the ability to analyse during examinations. Various useful models have developed over the years. The Faculty of Law at the UFS currently uses a model expounded by, amongst others, Maisel and Greenbaum, ${ }^{18}$ referred to as the FIRAC method of legal analysis (facts, issue, rule of law, application and conclusion). Regardless of the name given to a method of analysis, it is imperative that some method is used to lay the foundation for legal analysis. Moreover, it is important that all members of faculty are made aware of the fact that this method is taught to first-year students and that the method may be applied by students in all theory-based subjects in order to solve or analyse legal problems. According to Felsenburg and Graham ${ }^{19}$ the IRAC model, which is very similar to the FIRAC method used at some South African law faculties, is one of the most widely used for teaching beginner legal writers in American law schools. The IRAC method is described as:

"(1) a concise, precise statement of the issue (the legal question being addressed); (2) clear, precise, correct explanation of the rules of law that govern the resolution of the issue; (3) a thorough, well-reasoned, concise analysis of the rules that apply (or, in the case of a persuasive document, how the rules should apply) to the facts of the case; and (4) a short, helpful conclusion as to how the legal question will likely be, or should be, resolved.

Good analysis includes critical analysis. A particular method which is simple and easy to use is a reported judgment with a majority and minority judgment and which requires students to provide and motivate their preferences. Another pedagogy that may be employed for the development of critical analysis (this may also be used for a module in comprehension) is to take legislation or parts from legislation and ask students to redraft the given legislation in a more comprehensible manner.

\section{Summary of legal texts}

Linked to proper comprehension and analysis of legal texts, is the ability of a lawyer or law student to summarize a legal text in as brief, yet comprehensible a manner as possible. This ability lays the essential foundation for writing down legal opinions and, in particular, writing down heads of argument.

The ability to use words sparingly and "cutting to the bone" with regard to a legal problem is an essential ability employed by any legal practitioner. Again, this can only be achieved if a certain level of language proficiency is in place. Thus, whereas in a course or module in legal analysis students should be afforded greater leeway to express themselves in the space

Maisel and Greenbaum Introduction to Law and Legal Skills (2001) 95.

19 Felsenburg and Graham Felsenburg "Beginning Legal Writers in their Own Words: Why the First Weeks of Legal Writing are so Tough and What we can do About it" 2010 The Journal of the Legal Writing Institute 224 especially fn 3.

20 Felsenburg and Graham Felsenburg 2010 The Journal of the Legal Writing Institute 258. 
required by them, and as secondary outcome to come to grips with legal language (jargon), the next progression is to teach the ability of succinctly and clearly summarizing a legal text. This also develops good oral advocacy.

An innovative methodology used by a colleague in Legal History (and an example of how the integration of skills and theory can occur), is to use a lengthy letter written in 1889 by the then Chief Justice of the Union of South Africa to AG McGregor, later Attorney-General of the Free State, with regard to the need for the Union to establish a central court of appeal, as the basis for an assignment which requires the students to summarize the contents of the letter in one paragraph. ${ }^{21}$ In the process, the first-year students gain additional exposure to important legal principles, such as the principles of a fair trial.

\section{Research}

Research forms an integral part of the development of advocacy skills. The experience at the UFS, where an electronic "research" module is offered during the second year by UFS library staff ${ }^{22}$ is that, again, there exists no participation by the Faculty of Law in terms of what and how students are taught to conduct research, what the ideal outcomes of the module should be and how the research skills are to be integrated with theory. Legal research involves a great deal more than the ability to search for case law and statutes. Wonderful opportunities are therefore lost in the quest for the integration of theory and practice.

Legal History, Interpretation of Statutes, Constitutional Law and even Legal Philosophy may serve as a supplement to a legal-research course. In addition, such a course should address legal-writing and legal-research skills. ${ }^{23}$ All that would be required in order to achieve the ideal outcomes in these and other courses is cross-faculty or cross-departmental collaboration. Unfortunately, however, academics often seem reluctant to do so.

\section{Writing/drafting legal texts and referencing}

Legal writing should undoubtedly form an integral part of a holistic approach to the teaching of advocacy and should therefore be part of the LLB curriculum. Even from a purely academic perspective, Graves ${ }^{24}$ stresses the importance of writing as an effective learning tool as:

"(a) Contributing to intelligence by requiring analysis and synthesis of information.

21 Walker Lord De Villiers and his Times, South Africa 1842-1914 (1925) 111.

22 See Janto and Harrison-Cox "Teaching Legal Research: Past and Present" 1992 Law Library Journal 281-297 with regard to the US experience on librarians teaching legal research.

23 See Gabrielli "The Importance of Research and Legal Writing in the Law School Education" 1981 Albany LR 1-5 for Justice Gabrielli's view on legal writing and research skills.

$24 \mathrm{http}: / /$ www.fordfound.org/elibrary/documents/0123 (accessed 2009-06-18). 
(b) Development of initiative.

(c) Development of courage.

(d) Development of personal knowledge and self-esteem.

(e) Encouraging learning in many areas by employing auditory, visual and kinesthetic systems all at once.

(f) Improvement of reading skills."

\section{Oral communication of persuasive legal argument}

The final ability/competency is the presentation of a persuasive legal argument. There have been meaningful attempts to address these at most South African law faculties, mainly through the presentation of moot and mock trial assignments and participation in national and international mock/moot trial competitions. The Faculty of Law at the UFS participates in the All African Moot Court Competition, the annual Willem C Vis Commercial Arbitration Moot, the LexisNexis National Mock Trial Competition and the Kovsie First Year Moot Court Competition. It is the very existence of these activities that have sensitized the Faculty with regard to the severe lack of the remaining abilities and competencies that constitute "effective advocacy".

The practical problem with regard to advocacy-training is, of course, as with the teaching of writing, that it requires extensive practice, which makes it very labour-intensive and time-consuming. Participation in national and international mock/moot court competitions is generally expensive and only a relatively small number of students are exposed to and benefit from them. Another way in which to develop oral advocacy is to ask students to deliver short oral presentations in class, which would then count towards their semester mark. This method, which is used by a lecturer in Legal Philosophy, provides an outstanding means of achieving an integration of theory and skills.

As previously mentioned, the preceding abilities build upon one another; if one is missing, the end result is defective in one way or another. The groundwork for "persuasive" legal argument by way of illustration will have been laid in the legal-analysis module. Legal analysis would not have been possible if a certain level of comprehension through language had not been achieved.

\section{DESIGNING A LEGAL-WRITING COURSE FOR INCLUSION IN THE SOUTH AFRICAN LLB CURRICULUM}

When designing a legal-writing course for inclusion in the LLB curriculum, the following questions should be addressed: 


\section{What is the minimum level of language competency that will be needed to teach a legal-writing course?}

The answer to this question is compliance and collaboration with university entry requirements, any existing remedial courses (such as in extended courses), as well as any existing faculty language course requirements. This will inevitably involve cross-departmental and -faculty collaboration.

\section{Should language, particularly "legal language", form part of a legal-writing course?}

This question is closely linked to the first question. In the absence of a matrix used to indicate whether students are sufficiently equipped (with regard to language ability) for the study of law, this seems to be inevitable.

\section{Do law teachers have clarity as to what "legal language" is and are they equipped to teach language components of legal writing?}

Law teachers in a writing course must be equipped to speak and teach authoritatively on "legal language". If they are able to do so, the redundant conventions (amongst other aspects) that have been established over the centuries may slowly start to disappear from legal texts.

Haigh ${ }^{25}$ proceeds from the basis that legal English exists separately from ordinary English. He provides two reasons as to why it is sometimes difficult to understand legal English, namely (a) because the writing conventions are different, and (b) a large number of difficult words and phrases are used, which fall into four categories, including legal terms of art, legal jargon, legal meaning that differ from general meaning, and words that are used in peculiar contexts, other than the usual. According to Benson: ${ }^{26}$

"There is plentiful evidence that lawyer's language is hocus-pocus to non-
lawyers, and that non-lawyers cannot comprehend it. There exist scores of
empirical studies showing that most of the linguistic features found in legalese
cause comprehension difficulties. Legalese is characterized by passive verbs,
impersonality, nominalizations, long sentences, idea-stuffed sentences,
difficult words, double negatives, illogical order, poor headings, and poor
typeface and graphic layout. Each of these features alone is known to work
against clear understanding."

Therefore, the following questions arise, particularly in a South African context: Are law teachers adequately qualified to teach language as part of a legal-writing course? Are law teachers, specifically in a multi-cultural society, where the law teacher him/herself is often not a mother-tongue speaker of

Haigh Legal English (2009) 3.

Benson quoted by Gopen "The State of Legal Writing: Res Ipsa Loquitur" 1987 Michigan LR 334. 
English in particular, coming to the uncomfortable realization that, if legal education is to be addressed scientifically, teachers themselves should be equipped with the necessary formal language training?

\section{Do law students have clarity as to what is required in their legal writing?}

Lillis and Turner emphasize that so-called non-traditional students (or second-language students in South Africa) experience confusion with regard to what is required in their academic writing. ${ }^{27}$ Even basic terminology widely used and perceived by the teachers as common sense may be problematic for this group of students. Examples of the typical terminology that might not be easily understood include "avoid plagiarism", "cite authorities", "faulty grammar", "write an introduction", "argument", and "structure". ${ }^{28}$

\section{When should a legal-writing course take place?}

To answer this question, a number of sub-questions should be answered first: If language and writing modules are to be staggered, which seems to be an obvious option in view of an already "overcrowded" curriculum, how is it to be staggered? Should one not consider offering an introductory legalwriting course in the first year, which may then progress towards a more advanced course later in the programme? Or, in terms of an integrated process (that of theory and practice), opt for a model in which the traditional, theory-based subjects (or, in as many of them as possible) afford a greater amount of attention and weighting with regard to assessment in order to achieve effective and persuasive writing and research?

\section{How is good and persuasive legal writing to be effectively reinforced throughout all LLB courses?}

In view of the integration of theory and skills, as supported in this article, this would seem feasible on the condition that basic aspects imparted in such an introductory course are fully shared by all subjects offered at faculties.

\section{How can clarity concerning the subject matter of "legal writing" be achieved?}

It makes for varied and interesting reading to note the topics that are included by various authors under the broad classification of "legal writing". Undoubtedly, these differences (including different focl) are, in some instances, informed by variations with regard to process and practice (when international comparisons are made). In addition, particularly in the South

7 Lillis and Turner 2001 Teaching in Higher Education 58.

28 Lillis and Turner 2001 Teaching in Higher Education 88. 
African context, these differences are often informed by divisions within the South African profession. However, according to Stuckey what is clear, is "[w]hen objectives are not made explicit, the result is almost certainly a preoccupation with specific knowledge". ${ }^{29}$

As a general point of departure, there ought to be a clear distinction between legal drafting and legal writing. Is it writing legal essays (academic writing) we wish to teach and how can such writing have a positive impact on similar writing required in practice? Furthermore, should a legal-writing course also include legal drafting? If so, what type of drafting is to be included? It is suggested that the professions should be consulted with regard to the design of a legal-writing course.

\section{What resources are necessary to teach a legal- writing course?}

Cognisance must be taken of the fact that the teaching of legal writing is "an extremely difficult type of teaching". ${ }^{30}$ Heed should be taken of the oftenexpressed caution, such as that of Boyer ${ }^{31}$ that:

"Unlike other fundamental courses - contracts, torts, property, civil procedure and criminal and constitutional law - it cannot be adequately taught by the traditional methods of lecture on Socratic discourse. Nor can student achievement, in this course, be tested by a terms end examination. Legal writing requires steady work over the semester by both teachers and students

- 'close correction and one-to-one, oral teacher-student involvement' ..."

While the value of legal writing as an essential lawyering skill is widely recognized, typical faculty response to the course, as has been recorded in the United States, is voiced by Boyer as follows:

"Nearly everyone who writes about legal-writing courses, duly records faculty

disdain for the subject matter and administrative dislike of the expense."

It is doubtful whether the approaches taken by South African law faculties will be all that different from that recorded in the US. Faculties, therefore, will inevitably have to be prepared to invest substantially if a legal-writing course is to be instituted.

\section{CONCLUSION}

The main challenge in the area of developing legal-writing courses in South Africa involves the fact that legal academics (including "clinicians") have not been formally trained to teach language and writing. It is therefore proposed that we, in conjunction with the Law Deans' Association and the legal professions, including the judiciary, establish a course for the future and

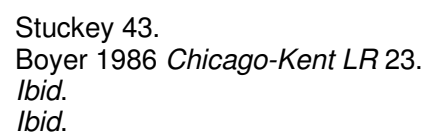


undergo training that will enable us to present these courses ourselves. Furthermore, we would like to suggest that all academic faculties become involved from the beginning. This may present an opportunity to sell coownership of legal writing to the faculty as a whole, which is part of the integrated process addressed in this article. ${ }^{33}$

It is clear that we cannot develop legal-writing courses if we do not have a clear vision with regard to what we aim to achieve.

33 Another option to be considered and that is not addressed in this article, is the so-called content-based learning concept. A law teacher and a language teacher may link their lectures and curriculum to complement each other. 